\title{
RELASI PIHAK EKSEKUTIF PERUSAHAAN DENGAN KANTOR AKUNTAN PUBLIK DAN PRAKTIK MANAJEMEN LABA
}

\author{
Williem ${ }^{1,}$ Oktavia $^{2}$
}

Fakultas Ekonomi dan Bisnis Universitas Kristen Krida Wacana

\section{A R T I C L E I N F O}

\author{
Article history: \\ Received 7 Mei 2019 \\ Revised 22 Mei 2019 \\ Accepted 17 Juni 2019
}

Key words:

Earnings management, public accounting firm, auditor and client relation

\begin{abstract}
A B S T R A C T
This study aims to examine the effect of relations between the executive of the company and Public Accounting Firm, which audits the company, on earnings management practices carried out by the management of the company. The research sample used by this study was 435 observations from manufacturing companies listed on the Indonesia Stock Exchange. The results of this study indicate that the relationship between the executive of the company and KAP which is currently audit the company negatively affects the practice of earnings management. This finding indicates that the practice of earnings management in companies with executives who have worked in public accounting firm that currently audit the companies is actually lower than in companies with executives have never worked in public accounting firm which is currently audit the companies. This research is the first study that measures the relationship between the executive of the company and public accounting firm, by tracing the profile of the company's executive in the annual report of the company or through $\mathrm{CV}$ (Curriculum Vitae) in the Google database.
\end{abstract}

\begin{abstract}
A B S T R A K
Penelitian ini bertujuan untuk menguji pengaruh relasi antara pihak eksekutif perusahaan dengan KAP (Kantor Akuntan Publik) yang mengaudit perusahaan terhadap praktik manajemen laba yang dilakukan oleh pihak manajemen perusahaan. Sampel penelitian yang digunakan oleh penelitian ini sebanyak 435 observasi dari perusahaan manufaktur yang terdaftar di Bursa Efek Indonesia. Hasil penelitian ini menunjukkan bahwa relasi antara pihak eksekutif perusahaan dengan KAP yang kini tengah mengaudit perusahaan berpengaruh negatif terhadap praktik manajemen laba. Temuan ini mengindikasikan bahwa praktik manajemen laba pada perusahaan dengan eksekutif yang pernah bekerja di KAP yang kini tengah mengaudit perusahaan ternyata lebih rendah dibandingkan pada perusahaan yang eksekutifnya tidak pernah bekerja di KAP yang kini tengah mengaudit perusahaan. Penelitian ini merupakan penelitian pertama yang mengukur relasi antara pihak eksekutif perusahaan dengan KAP yang mengaudit perusahaan, dengan cara menelusuri profil dari jajaran eksekutif perusahaan yang ada dalam laporan tahunan perusahaan maupun melalui CV (Curriculum Vitae) yang ada di database Google.
\end{abstract}

\section{PENDAHULUAN}

Investor pada dasarnya melakukan investasi terhadap perusahaan hanya dengan melihat atau hanya terpaku terhadap angka laba yang disajikan dalam laporan keuangan perusahaan yang terdaftar di pasar modal(Mursalim, 2005). Akibatnya, hal tersebut dapat memotivasi pihak manajerial peru-sahaan untuk melakukan manajemen laba dengan cara menampilkan angka laba yang diinginkan oleh pihak manajerial karena seperti yang kita ketahui pihak manajerial memiliki kelebihan untuk mem-peroleh insentif/bonus jika perusahaan memiliki laba yang baik(Watts \& Zimmerman, 1986).Oleh karena itu, peran auditor dalam hal ini sangat di-perlukan untuk mencegah tindakan manajemen laba yang bersifat oportunis (agresif), karena kita ketahui bahwa auditor adalah pihak independen di luar perusahaan yang bertugas untuk memberikan jasa assurance bagi perusahaan yang diaudit laporan keuangannya.

Namun pada kenyataannya auditor selaku pi-hak independen bisa luput juga dalam mendeteksi

*Corresponding author, email address:2oktavia@ukrida.ac.id 
kecurangan yang dilakukan oleh pihak manajemen perusahaan. Contoh kasus manipulasi laporan keuangan yang tidak terdeteksi adalah kasus antara British Telecom dengan Price Waterhouse Coopers mengenai fraud yang dilakukan oleh British Telecom tetapi tidak terdeteksi oleh kantor akuntan publiknya yaitu Price Waterhouse Coopers. Namun, fraud akuntansi yang dilakukan British Telecom ini justru terdeteksi oleh seorang pelapor pengaduan (whistleblower) dan setelah itu diteruskan kasusnya oleh akuntansi forensik dari KPMG. Modus kecurangan akuntansi yang dilakukan oleh British Telecom adalah dengan cara menggelembungkan revenue perusahaan dengan cara melakukan perpanjangan kontrak palsu dan invoice palsu disertai dengan melakukan transaksi gelap dengan vendor terkait. Tindakan fraud/kecurangan ini sudah dilakukan sejak tahun 2013 dan motivasi dari terja-dinya tindakan ini dikarenakan adanya dorongan mendapatkan bonus. Dampak dari fraud pengge-lembungan dana yang dilakukan oleh British Tele-com menyebabkan mereka harus menurunkan GBP 530 juta dan harus memotong arus kas selama ta-hun tersebut sebanyak GBP 500 juta untuk mem-bayar utang-utang yang disembunyikan (Priantara, 2017). Selain itu, hal ini juga memiliki dampak yang berpengaruh besar kepada investor dikarenakan harga lembar saham yang dimiliki British Telecom mengalami kerugian, sahamnya mengalami penu-runan 20\% ketika British Telecom mengumumkan koreksi pendapatannya sebesar GBP 530 juta pada bulan Januari 2017(Nuralimah, 2017).

Berdasarkan skandal yang terjadi antara Brit-ish Telecom dan Price Waterhouse Coopers tersebut, maka relasi antara pihak eksekutif perusahaan dengan KAP (Kantor Akuntan Publik) dapat men-jadi salah satu faktor pemicu dilakukannya praktik manajemen laba oleh perusahaan. Penelitian yang dilakukan oleh Chi et al. (2011) dan Inaam et al. (2012) meneliti pengaruh lamanya ikatan auditor dengan perusahaan (yang diproksikan dengan au-dit tenure) terhadap praktik manajemen laba riil. Mereka menemukan bahwa semakin lama ikatan yang terjalin antara auditor dengan perusahaan, maka semakin tinggi praktik manajemen laba riil yang dilakukan oleh perusahaan.

Lebih lanjut, penelitian yang dilakukan oleh Ball et al. (2015) meneliti apakah audit tenure yang berlangsung antara pihak klien dengan auditor memiliki pengaruh terhadap kualitas audit. Audit tenure dalam penelitiannya digunakan untuk mengukur relasi antara pihak eksekutif perusahaan dengan KAP, dan akrual diskresioner digunakan sebagai ukuran dari kualitas audit. Ball et al. (2015) menemukan bahwa semakin lama audit tenure maka semakin tinggi akrual diskresionernya. Hasil ini menunjukkan bahwa semakin lama relasi yang terjalin antara pihak eksekutif perusahaan dengan KAP, maka semakin rendah kualitas audit yang diberikan oleh KAP.

Wisanggeni dan Ghozali (2017) juga meneliti mengenai hubungan antara auditor relationships dan kualitas audit. Penelitian Wisanggeni \& Ghozali (2017) tersebut mengukur auditor relationships den-gan menggunakan audit tenure. Hasil penelitian mereka adalah semakin lama hubungan yang terja-lin antara auditor dengan perusahaan (dalam hal ini audit tenure), maka semakin rendah kualitas audit yang dihasilkan.

Penelitian ini bertujuan untuk menguji penga-ruh dari relasi perusahaan dengan KAP terhadap praktik manajemen laba, yang diukur mengguna-kan akrual diskresioner. Perbedaan penelitian ini dengan penelitian sebelumnya (Chi et al., 2011; Inaam et al., 2012; Ball et al., 2015; Wisanggeni \& Ghozali, 2017) terletak pada ukuran relasi antara pihak eksekutif dengan KAP. Pengukuran yang digunakan oleh peneliti sebelumnya menggunakan audit tenure untuk mengukur relasi antara pihak eksekutif perusahaan dengan KAP. Berbeda dengan penelitian sebelumnya, penelitian ini menggunakan metode yang berbeda ketika mengukur relasi antara pihak eksekutif dengan KAP yang kini tengah mengaudit perusahaan, yaitu dengan cara melihat profil jajaran eksekutif perusahaan pada laporan tahunan maupun CV yang ada di database google, dan kemudian dilanjutkan melihat apakah jajaran eksekutif perusahaan tersebut pernah bekerja di KAP yang kini tengah mengaudit perusahaan tempat para eksekutif tersebut bekerja. Penelitian ini merupakan penelitian pertama yang mengukur relasi antara pihak eksekutif perusahaan dengan KAP dengan cara menelusuri profil dari jajaran eksekutif perusahaan. Alasan yang memotivasi mengapa penelitian ini tidak menggunakan audit tenure adalah karena ukuran tersebut dianggap kurang relevan dalam mengukur relasi antara pe-rusahaan dengan KAP. Dalam rangka menjaga independensi auditor, Pemerintah Republik Indo-nesia telah mengeluarkan peraturan mengenai ro-tasi auditor yang bertujuan untuk membatasi la-manya perikatan auditor dengan perusahaan, se-hingga proksi audit tenure kini dianggap kurang tepat dalam mengukur relasi antara perusahaan dengan KAP. 


\section{TELAAH LITERATUR DAN PENGEMBANGAN HIPOTESIS Teori Keagenan}

Menurut Jensen dan Meckling (1976), hubungan keagenan merupakan sebuah kontrak antara satu atau lebih pemilik (principal) dengan manajer (agent) yang melakukan pekerjaannya demi kepentingan pemilik, termasuk mendelegasikan kekuasaan kepada manajer tersebut dalam mengambil keputusan untuk kepentingan pemilik. Hubungan keagenan tersebut akan menimbulkan konflik yang dinamakan konflik keagenan (agency conflict) apabila manajer selaku agen berusaha untuk memaksimalkan kesejahteraan pribadinya dan bertindak untuk kepentingannya sendiri (Jensen \& Meckling, 1976).

Manajer memiliki informasi yang jauh lebih banyak mengenai kondisi internal perusahaan dibandingkan dengan pemilik. Maka, manajer perusahaan diwajibkan untuk menyajikan informasi terkait dengan kondisi perusahaan secara berkala kepada pemilik perusahaan. Kesenjangan informasi tersebut dikenal dengan istilah asimetri informasi (asymmetric information). Dalam rangka memaksimalkan kesejahteraan pribadinya maka manajer selaku agen dapat memanfaatkan kesenjangan informasi yang dimilikinya untuk melakukan praktik manajemen laba yang bersifat oportunis (agresif) dengan cara menutupi informasi-informasi yang sebenarnya dan menampilkan atau menyajikan informasi yang sesuai dengan apa yang ingin manajer tampilkan, terutama apabila pengukuran dari kinerja manajer itu sendiri dipengaruhi oleh informasi yang disajikannya.

Praktik manajemen laba yang bersifat oportunis dapat menyebabkan reliabilitas informasi laporan keuangan menjadi berkurang, dan pada gilirannya dapat menyesatkan investor (pemilik) karena mereka tidak mendapatkan informasi yang akurat mengenai kinerja perusahaan secara real(Murwaningsari, 2011; Oktavia, 2017). Dampak dari hal ini adalah investor dapat membuat keputusan yang salah dalam melakukan investasi. Oleh karena itu, untuk memastikan bahwa manajer melaksanakan tugasnya sesuai dengan kepentingan pemilik, maka timbul biaya yang disebut biaya keagenan (agency cost), yaitu biaya monitoring dan biaya pengikatan (bonding), dalam rangka mengatasi konflik keagenan tersebut (Jensen \& Meckling, 1976).

\section{Manajemen Laba}

Menurut Heally dan Wahlen (1999) manajemen laba dapat terjadi pada saat seorang manajermemberikan keputusannya dalam membuat laporan keuangan dan ketika melakukan penyusunan transaksi untuk dengan sengaja mengubah laporan keuangan baik untuk menimbulkan gambaran yang tidak benar bagi para pemangku kepentingan (stakeholders)mengenai kinerja perusahaan ataupun untuk mempengaruhi hasil kontrak yang bergantung pada angka-angka akuntansi yang dilaporkan (Wahlen \& Heally, 1999). Dapat disimpulkan bahwa manajemen laba merupakan suatu upaya yang dengan sengaja dilakukan untuk mengatur keuntunganuntuk kepentingan-kepentingan tertentu yang didasari oleh faktor-faktor ekonomi tertentu. Berikut dua metode atau cara untuk memahami manajemen laba, yaitu sebagai berikut:

a. Oportunis:Memandang manajemen laba sebagai perilaku yang oportunis dari seorang manajer untuk memaksimalkan utilitasnya dalam menghadapi kontrak kompensasi, utang, dan biaya politik (Wahlen \& Heally, 1999).

b. Efisien: Melihat manajemen laba dari cara pandanga kontrak yang efisien, yang memiliki arti manajemen laba memberikan fleksibilitas bagi para manajer untuk dapat melindungi diri sendiri serta perusahaan dalam mengantisipasi kejadian-kejadian yang tak terduga untuk keuntungan seluruh pihak yang terlibat dalam kontrak (Wahlen \& Heally, 1999).

Scott (2015) mengemukakan beberapa motivasi terjadinya praktik manajemen laba:

a. Bonus Purpose

Manajer yang memiliki asimetri informasi dengan investor akan bertindak secara oportunis untuk mengatur laba bersih yang akan dilaporkan agar dapat mendapatkan bonus yang maksimal berdasarkan kontrak yang dimiliki oleh perusahaan.

b. Political Motivations

Manajemen laba digunakan untuk mengurangi laba yang dilaporkan pada perusahaan terbuka. Dikarenakan adanya tekanan publik, perusahaan cenderung mengurangi laba yang dilaporkan karena hal tersebut dapat mengakibatkan pemerintah menetapkan aturan yang lebih ketat. 
c. Taxation Motivation

Praktik manajemen laba dapat terjadi pada umumnya salah satunya dikarenakan motivasi perusahaan untuk melakukan penghematan pajak. Berbagai metode akuntansi akan dilakukan bertujuan untuk melakukan penghematan pajak pendapatan.

d. Pergantian CEO

Wajar nampaknya jika sebelum terjadinya pergantian CEO, CEO yang lama ketika mendekati masa pensiun akan menaikkan laba dalam rangka meningkatkan bonus mereka. Selain itu, CEO yang gagal dalam memperbaiki kinerja perusahaannya, mereka juga cenderung akan memaksimalkan laba perusahaan agar performa mereka terlihat baik dan potensi mereka untuk diberhentikan akan berkurang.

e. Initial Public Offering (IPO)

Perusahaan terbuka atau yang biasanya kita sebut go-public pada umumnyabelum memiliki harga pasar sehingga mereka perlu melakukan penetapan nilai saham yang akan mereka tawarkan. Hal ini secara tidak langsung akan membuat para manajer yang perusahaannya go-public melakukan praktik manajemen laba agar memperoleh nilai saham yang lebih tinggi.

f. Pentingnya Memberi Informasi terhadap Investor

Informasi yang terkait dengan kinerja perusahaan wajib dilaporkan kepada investor. Hal tersebut perlu dilakukan agar investor dapat menilai apakah kondisi perusahaan pada saat itu sedang dalam kondisi yang baik atau tidak.

\section{Relasi Pihak Eksekutif Perusahaan dengan KAP}

Dalam penelitian Buntara (2016) relasi yang dimaksud merupakan relasi yang terbentuk melalui perjanjian kontrak perusahaan dengan KAP atau yang kita kenal dengan istilah audit tenure. Berdasarkan isi PMK No. 17 tanggal 5 Februari 2008, beberapa hal dalam peraturan ini dapat menjadi perhatian, yaitu mengenai pemberian jasa audit umum atas laporan keuangan dari suatu entitas sebagaimana dimaksud dalam Pasar 2 ayat (1) huruf a dilakukan oleh KAP dapat dilakukan paling lama untuk 6 (enam) tahun buku berturut-turut dan oleh seorang Akuntan Publik paling lama untuk 3 (tiga) tahun buku berturutturut. (Pasar 3 ayat (1)).Akuntan Publik sebagaimana dimaksud pada ayat (1) dapat menerima kembali penugasan audit umum untuk klien sebagaimana dimaksud pada ayat (1) setelah 1 (satu) tahun buku tidak memberikan jasa audit umum atas laporan keuangan klien tersebut (ayat (2)) (Peraturan Menteri Keuangan, 2008).

Berdasarkan pengaturan dalam PMK No.17, sebuah Kantor Akuntan Publik (KAP) hanya boleh mengaudit sebuah perusahaan paling lama 6 (enam) tahun buku berturut-turut, sedangkan bagi Akuntan Publik di dalam KAP tersebut hanya diperbolehkan mengaudit paling lama 3 (tiga) tahun buku berturut-turut. Peraturan yang baru sudah diterbitkan oleh pemerintah Pada tanggal 6 April 2015, dengan nomor Peraturan Pemerintah (PP) No. 20 tahun 2015 mengenai Praktik Akuntan Publik (PP 20/2015) dimana ada beberapa bagian dari Undang-undang No.5 tahun 2011 tentang Akuntan Publik yang direvisi dan disempurnakan (Peraturan Menteri Keuangan, 2008).

Berkaitan mengenai peraturan rotasi jasa akuntan publik yang diatur di dalam Pasal 11 PP 20/2015 dimana pemberian jasa audit atas informasi keuangan historis sebagaimana dimaksud dalam Pasal 10 ayat (1) huruf a terhadap suatu entitas oleh seorang Akuntan Publik dibatasi paling lama untuk 5 (lima) tahun buku berturut-turut (Pasal 11 ayat (1)). Pembatasan pemberian jasa audit atas informasi keuangan historis sebagaimana dimaksud pada ayat (1) dan ayat (2) juga berlaku bagi Akuntan Publik yang merupakan Pihak Terasosiasi (ayat (3)); Didalam penjelasan pada ayat 3 disebutkan bahwa yang dimaksud dengan "Akuntan Publik yang merupakan Pihak Terasosiasi" menurut pengubahan peraturan diatas adalah akuntan publik yang terlibat langsung dalam pemberian jasa assurance tetapi mereka tidak menandatangani laporan auditor independen, seperti Akuntan Publik yang merupakan partner in charge dalam suatu perikatan audit (Peraturan Pemerintah, 2015).

Penelitian ini mengukur relasi yang dimaksud menggunakan riwayat kerja eksekutif perusahaan yang dicantumkan dalam laporan tahunan perusahaan maupun CV yang ada di database google. Relasi akan terbangun jika pihak eksekutif perusahaan pernah bekerja di KAP yang mengaudit perusahaan dimana eksekutif tersebut menjabat. Jika didapati salah satu dari eksekutif perusahaan pernah menjabat di KAP yang mengaudit perusahaan tersebut maka dapat diindikasikan bahwa terdapat relasi antara pihak eksekutif dengan KAP yang tengah mengaudit perusahaan tersebut. 


\section{Hipotesis}

Chi et al. (2011) dan Inaam et al. (2012) menguji pengaruh lamanya ikatan auditor dengan peru-sahaan terhadap praktik manajemen laba riil. Pene-litian mereka menggunakan auditor tenure untuk mengukur relasi antara pihak perusahaan dengan pihak auditor. Temuan Chi et al. (2011) dan Inaam et al. (2012) ini menunjukkan bahwa semakin lama relasi yang terjalin antara pihak perusahaan dengan pihak auditor, maka semakin tinggi praktik manajemen laba riil yang dilakukan oleh perusa-haan.

Menurut Ball et al. (2015) yang menyelidiki faktor hubungan interpersonal antara Partner KAP dan CEO perusahaanterhadap kualitas audit (den-gan memakai sampel perusahaan di Australia), menemukan bahwa pengurangan kualitas audit terjadi ketika hubungan interpersonal antara part-ner dan CEO perusahaan klien semakin erat. Ball et al. (2015) mengukur kualitas audit menggunakan akrual diskresioner, yang juga merupakan alat un-tuk mengukur praktik manajemen laba. Dapat dis-impulkan bahwa berdasarkan penelitian Ball et al. (2015) tersebut, pengaruh relasi antara partner audit dengan CEO terhadap praktik manajemen laba (tingkat akrual diskresioner) memiliki pengaruh yang positif, yang berarti jika semakin lama relasi antara partner audit dengan CEO terjalin, maka akan menyebabkan tingkat akrual diskresioner perusahaan menjadi semakin tinggi.

Dengan menggunakan ukuran relasi yang berbeda dengan penelitian Chi et al. (2011), Inaam et al. (2012), maupun Ball et al. (2015), penelitian ini akan menguji kembali pengaruh dari relasi antara eksekutif perusahaan dengan KAP terhadap praktik manajemen laba. Berdasarkan uraian di atas, dikembangkan hipotesis sebagai berikut:

H1 : Relasi pihak eksekutif perusahaan dengan KAP berpengaruh positif terhadap praktik manajemen laba

\section{METODE PENELITIAN \\ Data dan Sampel Penelitian}

Penelitian ini menggunakan data sekunder berupa laporan tahunan perusahaan manufaktur ta-hun 2015-2017. Data laporan tahunan perusahaan manufaktur tersebut diperoleh dari website www.idx.co.id. Sampel yang digunakan pada pe-nelitian adalah perusahaan manufaktur yang ter-daftar di Bursa Efek Indonesia (BEI) dan memiliki kelengkapan data yang diperlukan oleh penelitian ini.Tabel 1 menyajikan proses pemilihan sampel dalam penelitian ini. Sampel yang diambil pada penelitian ini merupakan perusahaan-perusahaan yang berada di dalam sektor manufaktur yang telah terdaftar di Bursa Efek Indonesia pada tahun 2017. Dilansir dari Indonesian Capital Market Directory (ICMD), terdapat 154 perusahaan manufaktur yang terdaftar di BEI pada tahun 2017serta terdapat 1 perusahaan yang dikeluarkan dari penelitian di-karenakan delisting. Selanjutnya,setelah dilakukan-nya seleksi terhadap kebutuhan penelitian, peneliti mengeluarkan beberapa perusahaan-perusahaan yang datanya tidak memenuhi kriteria dan memperoleh total perusahaan yang diobservasi yaitu sebanyak 435 sampel.

Tabel 1. Proses Pemilihan Sampel

\begin{tabular}{|c|c|c|c|}
\hline \multicolumn{3}{|c|}{$\begin{array}{l}\text { Jumlah perusahaan yang terdaftar di } \\
\text { BEI pada tahun } 2017\end{array}$} & 154 \\
\hline \multicolumn{3}{|c|}{$\begin{array}{l}\text { Jumlah perusahan yang delisting pada } \\
\text { periode penelitian }\end{array}$} & (1) \\
\hline \multicolumn{3}{|c|}{ Total Perusahaan } & 153 \\
\hline Tahun & Sampel & $\begin{array}{l}\text { Jumlah Perusa- } \\
\text { haan yang tidak } \\
\text { memiliki ke- } \\
\text { lengkapan data }\end{array}$ & Observasi \\
\hline 2015 & 153 & (11) & 142 \\
\hline 2016 & 153 & (10) & 143 \\
\hline 2017 & 153 & (3) & 150 \\
\hline \multicolumn{3}{|c|}{ Total Observasi final } & 435 \\
\hline
\end{tabular}

\section{Model Penelitian}

Model penelitian yang akan digunakan untuk menguji hipotesis penelitian ini dianalisis menggunakan analisis regresi berganda. Berikut adalah model penelitian ini:

$\mathrm{EM}=a+\beta_{1} \mathrm{RLS}+\beta_{2} \mathrm{RKAP}+\beta_{3} \mathrm{ROA}+\beta_{4} \mathrm{SIZE}+e$ 


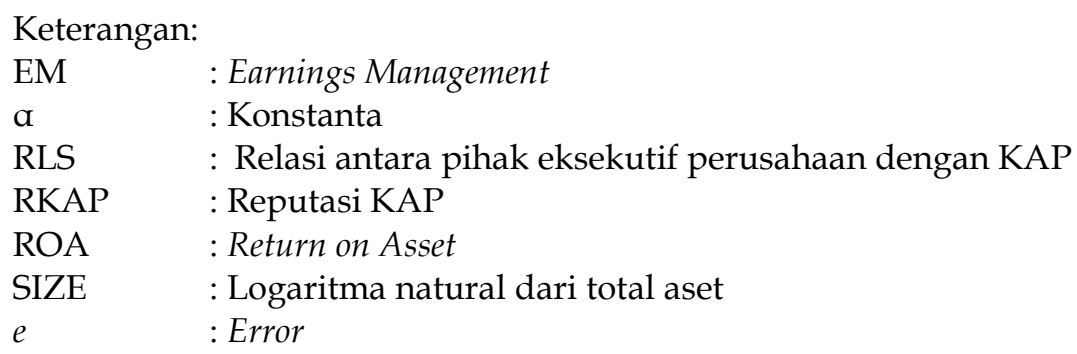

\section{Operasional Variabel}

Penelitian ini menggunakan variabel-variabel penelitian berikut ini:

a. Manajemen Laba

Model ini diadopsi dari model Kothari et al. (2005) dan digunakan untuk mendekomposisi total akrual menjadi komponen akrual diskresioner dan akrual non diskresioner pada penelitian ini. Komponen akrual diskresioner merupakan residual dari model berikut ini:

ACCit $/$ TAit-1= a1 $(1 /$ TAit-1 $)+\beta 1((\Delta$ REVit- $\Delta$ RECit $) /$ TAit-1 $)+\beta 2($ PPEit/TAit-1 $)+\beta 3($ ROAit $)+\varepsilon i t$

Keterangan:

ACC = Total akrual yaitu laba tahun berjalan dari operasi yang dilanjutkan dikurangi arus kas dari operasi (CFO) diskala dengan total aset tahun sebelumnya

TAit-1 = Total aset pada tahun $\mathrm{t}-1$

$\triangle \mathrm{REV} \quad=$ Perubahan pendapatan diskala dengan total aset tahunsebelumnya

$\triangle \mathrm{REC} \quad=$ Perubahan piutang usaha diskala dengan total aset tahun sebelumnya

PPE = Aset tetap diskala dengan total aset tahun sebelumnya

ROA = Return on asset (yaitu, rasio laba bersih terhadap total aset tahun sebelumnya).

b. Relasi Pihak Eksekutif Perusahaan dengan KAP

Relasi antara eksekutif perusahaan dengan KAP (RLS) diukur menggunakan variable Dummy, dimana angka 1 merepresentasikan ada eksekutif perusahaan yang memiliki riwayat kerja di KAP yang kini tengah mengaudit perusahaan tersebut dan angka 0 merepresentasikan tidak ada eksekutif perusahaan yang memiliki riwayat kerja di KAP yang mengaudit perusahaan tersebut. Untuk menelusuri ada tidaknya relasi tersebut, penelitian ini menelusuri profil eksekutif yang ada di laporan tahunan maupun CV yang ada di database google.

c. Variabel Control

Variabel control yang digunakan dalam penelitian ini adalah Reputasi KAP (RKAP), profitabilitas (ROA), dan SIZE. Reputasi KAP diukur dengan menggunakan variable Dummy, di mana angka 1 merepresentasikanperusahaan diaudit oleh KAP big four sedangkan angka 0 merepresentasikan pe-rusahaan diaudit oleh KAP non-big four. Nadia (2015) dan Riswandi et al. (2012) menemukan bah-wa reputasi KAP berpengaruh negatif terhadap praktik manajemen laba. Semakin baik reputasi KAP, maka semakin rendah praktik manajemen laba yang dilakukan oleh perusahaan. Profitabilitas perusahaan yang diukur dengan menggunakan rasio ROA (Return on Assets), yang dihitung dengan cara membagi laba bersih perusahaan dengan total aset perusahaan, digunakan untuk mengontrol pengaruh dari profitabilitas perusahaan terhadap praktik manajemen laba perusahaan. Menurut bonus plan hypothesis yang dikemukakan oleh Watts dan Zimmerman (1986), manajer cenderung termotivasi untuk melakukan praktik manajemen laba yang dapat meningkatkan laba perusahaan, apabila perusahaan memberikan bonus kepada manajernya berdasarkan pada angka laba. Ukuran perusahaan (SIZE) dipilih sebagai variabel kontrol untuk men-gontrol pengaruh dari ukuran perusahaan terhadap besaran manajemen laba. Penelitian yang dilakukan oleh Siregar \& Utama (2008) dan Oktavia (2017) menemukan bahwa semakin besar ukuran perusahaan, semakin kecil manajemen laba yang dilakukan oleh perusahaan. Hal ini dikarenakan perusahaan besar cenderung mendapatkan sorotan yang lebih besar dari analis maupun investor di-bandingkan dengan perusahaan kecil, sehingga membuat perusahaan besar lebih berhati-hati da-lam bertindak. Ukuran perusahaan (size) dalam penelitian ini diukur dengan menggunakan loga-ritma natural dari total aset. 


\section{HASIL PENELITIAN DAN PEMBAHASAN \\ Statistik Deskriptif}

Pada tabel 2 dapat dilihat bahwa variabel manajemen laba (EM) memiliki nilai rata-rata sebesar 0,0682 serta standar deviasi sebesar 0,1190, yang mengindikasikan variasi tinggi pada manajemen laba. Tingkat manajemen laba tertinggi berada di angka 1,4435 yang dimiliki oleh perusahaan Mark Dynamics Indonesia Tbk pada tahun 2017 dan tingkat manajemen laba terendah di angka 0,0001 yang dimiliki oleh perusahaan Kedawung Setia Industrial Tbk pada tahun 2016. Dapat diketahui pula bahwa proporsi dummy untuk variabel relasi antara eksekutif perusahaan dengan KAP yang mengaudit (RLS) sebanyak 5,29\% yang memiliki relasi dan sebanyak $94,71 \%$ tidak memiliki relasi.

Dari Tabel 2 diketahui bahwa 38,39\% perusahaan sampel diaudit oleh KAP big four dan sisanya sebanyak 61,61\% diaudit oleh KAP non-big four. Variabel profitabilitas (ROA) memiliki nilai rata-rata sebesar 0,0535 dengan nilai standar deviasi profitabilitas sebesar 0,2687. Selanjutnya, variabel ukuran perusahaan (SIZE) memiliki nilai rata-rata sebesar 28,1952, dan standar deviasi sebesar 1,6093. Rata-rata profitabilitas yang positif menunjukan bahwa perusahaan sampel dalam kondisi menghasilkan laba.

Tabel 2. Statistik Deskriptif

\begin{tabular}{|l|l|l|l|l|l|l|}
\hline Variabel & N & Mean & $\begin{array}{c}\text { Me- } \\
\text { dian }\end{array}$ & Min. & Max. & $\begin{array}{c}\text { Std. } \\
\text { Dev }\end{array}$ \\
\hline EM & 435 & 0.0723 & 0.0434 & 0.0001 & 1.4435 & 0.1212 \\
\hline ROA & 435 & 0.0535 & 0.0310 & -0.3727 & 2.6832 & 0.2687 \\
\hline SIZE & 435 & $\begin{array}{l}28.354 \\
3\end{array}$ & 28.1952 & 22.7577 & 33.3202 & 1.6093 \\
\hline \multicolumn{3}{|c|}{} & \multicolumn{3}{c|}{$\begin{array}{c}\text { Proporsi } \\
\text { Dummy =1 }\end{array}$} & \multicolumn{2}{c|}{$\begin{array}{c}\text { Proporsi } \\
\text { Dummy = 0 }\end{array}$} \\
\hline \multicolumn{3}{|c|}{ RLS } & \multicolumn{3}{c|}{$5.29 \%$} & \multicolumn{3}{c|}{$38.71 \%$} \\
\hline RKAP & \multicolumn{3}{c}{$38.39 \%$} & $61.61 \%$ \\
\hline
\end{tabular}

Pengujian Asumsi Klasik

Model penelitian ini dipastikan tidak menga-lami masalah heteroskedastisitas karena software EViews memiliki fasilitas untuk mengatasi masalah heteroskedastisitas, dimana software dapat melakukan respesifikasi covariance white, sehingga dapat dipastikan bahwa model penelitian ini terbebas dari masalah heteroskedastisitas.

Tabel 3 menyajikan hasil pengujian multikoli-nearitas. Berdasarkan Tabel 3, hubungan antara variabel-variabel independen serta variabel-variabel kontrolnya tidaklah kuat, dikarenakan hasil dari uji multikolinieritas kurang dari 0,8. Dari hasil penelitian ini dapat disimpulkan bahwa hubungan antara variabel RLS, RKAP, ROA dan SIZE tidak memiliki masalah multikolinearitas.

Tabel 3. Hasil Pengujian Multikolinearitas

\begin{tabular}{|c|c|c|c|c|}
\hline & RLS & RKAP & ROA & SIZE \\
\hline RLS & 1 & 0.2993 & 0.0024 & 0.2184 \\
\hline RKAP & 0.2993 & 1 & 0.1014 & 0.4692 \\
\hline ROA & 0.0024 & 0.1014 & 1 & 0.0947 \\
\hline SIZE & 0.2184 & 0.4692 & 0,0947 & 1 \\
\hline
\end{tabular}

Nilai Durbin-Watson stat pada penelitian ini diketahui sebesar 1,9151. Nilai ini masih dalam range bebas masalah autokolerasi yaitu 1,54-2,46 (Winarno, 2017), sehingga model penelitian ini dipastikan bebas dari masalah autokolerasi.

\section{Hasil Pengujian Hipotesis}

Tabel 4 menunjukkan hasil pengujian pengaruh relasi antara pihak eksekutif perusahaan dengan KAP yang mengaudit terhadap praktik manajemen laba.Dari tabel tersebut dapat dilihat bahwa model estimasimemiliki R-square sebesar 5,66\%. Artinya variabel independen dari penelitian ini mampu menjelaskan variabel dependen (dalam hal ini praktik manajemen laba) sebesar 5,66\%, sementara sisanya 94,34\% dipengaruhi oleh variabel-variabel lain di luar variabel independen yang digunakan pada penelitian ini.Dalam mengukur apakah model penelitian ini layak atau tidak untuk memprediksi variabel dependen, dapat dilihat dari hasil uji F. Dari tabel 4diketahui bahwa model estimasi memiliki nilai Prob (F-stat) yang signifikan 
pada tingkat signifikansi 5\%. Artinya model penelitian ini cukup layak untuk menguji hipotesis penelitian ini.

Tabel 4. Hasil Pengujian Hipotesis

\begin{tabular}{|c|c|c|c|}
\hline \multicolumn{4}{|c|}{$\mathrm{EM}=\alpha+\beta_{1} \mathrm{RLS}+\beta_{2} \mathrm{RKAP}+\beta_{3} \mathrm{ROA}+\beta_{4} \mathrm{SIZE}+e$} \\
\hline Variabel & Koefisien & t-stat & Sig. \\
\hline RLS & -0.0253 & -2.0835 & ** 0.0378 \\
\hline RKAP & -0.0016 & -0.1463 & 0.8837 \\
\hline ROA & 0.0922 & 1.1872 & 0.2358 \\
\hline SIZE & -0.0066 & -1.3453 & 0.1792 \\
\hline Konstanta & 0.2577 & 1.8362 & $* 0.0670$ \\
\hline $\mathbf{N}$ & 435 & & \\
\hline Adj. R $^{2}$ & $5.66 \%$ & & \\
\hline F-Stat & 2.9396 & & \\
\hline Prob. F-stat & $* * 0.0203$ & & \\
\hline Signifikan $\mathrm{p}$ & ** level 5\%; & $10 \%$ & \\
\hline
\end{tabular}

Dari Tabel 4 dapat dilihat bahwa relasi antara pihak eksekutif perusahaan dengan KAP yang mengaudit (RLS) memiliki koefisien yang bernilai negatif dan signifikan. Hasil ini menunjukan bahwa pengaruh relasi antara pihak eksekutif perusahaan dengan KAP terhadap praktik manajemen laba adalah negatif dan signifikan. Artinya, praktik manajemen laba lebih rendah pada perusahaan yang memiliki eksekutif yang pernah bekerja di KAP yang kini tengah mengaudit perusahaan. Temuan ini menunjukkan bahwa hipotesis $\mathrm{H} 1$ pada penelitian ini tidak terbukti.

Terdapat beberapa alasan mengapa relasi antara eksekutif perusahaan dengan KAP ber-hubungan negatif dengan praktik manajemen laba. Pertama, penelitian ini menunjukkan bahwa peru-sahaan yang memiliki eksekutif pernah bekerja di KAP yang kini tengah mengaudit perusahaan se-banyak 5,29\% dari total sampel, dan semua ekse-kutif perusahaan tersebut berasal dari KAP big four. Oleh karena KAP big four memiliki reputasi yang baik dan diakui secara global, maka pegawai di KAP big four tentunya sangat profesional dan memiliki integritas tinggi. Apalagi KAP big four menerapkan tingkat seleksi yang ketat terhadap calon pegawainya, sehingga sudah dipastikan para pegawai yang masuk di KAP tersebut memiliki kemampuan yang teruji dan berintegritas tinggi. Oleh karena itu, pihak eksekutif perusahaan yang memiliki pengalaman kerja di KAP big four dipasti-kan dapat bersikap profesional, memiliki kemam-puan yang terpercaya, dan memiliki integritas yang baik. Hal inilah yang membuat keberadaan ekse-kutif perusahaan (yang pernah bekerja di KAP big four) tersebut justru mengurangi praktik manajemen laba akrual perusahaan, karena mereka tidak menolerir praktik manajemen laba yang bersifat agresif, yang dapat merugikan investor maupun nama baiknya. Kedua, karena penelitian ini mene-mukan bahwa pihak eksekutif yang pernah bekerja di KAP yang kini tengah mengaudit perusahaanya merupakan pihak eksekutif yang berasal dari KAP big four, maka pihak eksekutif tersebut tidak ingin jika KAP (yaitu tempat dimana eksekutif tersebut pernah bekerja) mendapatkan reputasi yang buruk apabila dirinya terlibat dalam praktik manajemen laba yang agresif dan oportunis. Ditambah lagi dengan reputasi baik yang melekat di diri eksekutif tersebut bahwa dirinya merupakan jebolan KAP big four, tentunya membuat keberadaan dari eksekutif ini dapat mengurangi praktik manajemen laba yang bersifat agresif dan oportunis, yang tentunya dapat merusak reputasi eksekutif tersebut maupun KAP big four tempat dulunya mereka bekerja.

Dari Tabel 4, diketahui pula bahwa variabel-variabel kontrol yang digunakan dalam penelitian ini (yaitu, reputasi KAP, profitabilitas, dan ukuran perusahaan) tidak berpengaruh terhadap praktik manajemen laba perusahaan.

\section{SIMPULAN, KETERBATASAN DAN SARAN}

Hasil pengujian menunjukkan bahwa relasi pihak eksekutif perusahaan dengan KAP yang kini tengah mengaudit perusahaan berpengaruh negatif terhadap praktik manajemen laba perusahaan. Temuan ini menunjukkan bahwa tingkat manajemen laba pada perusahaan dengan eksekutif yang per-nah bekerja di KAP yang kini tengah mengaudit perusahaan ternyata lebih rendah dibandingkan pada perusahaan yang eksekutifnya tidak pernah bekerja di KAP yang kini tengah mengaudit peru-sahaan. Dengan kata lain, relasi yang erat antara pihak eksekutif dengan KAP yang kini tengah mengaudit perusahaan, ternyata tidak mening-katkan praktik manajemen laba perusahaan. Te-muan ini tidak sejalan dengan hipotesis yang dikembangkan dalam penelitian ini yang menyatakan bahwa relasi pihak eksekutif dengan KAP berpengaruh positif terhadap praktik manajemen laba. Penjelasan mengapa relasi pihak eksekutif perusa-haan 
dengan KAP yang kini tengah mengaudit perusahaan justru mengurangi praktik manajemen laba perusahaan adalah karena pihak eksekutif perusahaan yang terdeteksi pernah bekerja di KAP yang kini tengah mengaudit perusahaan adalah pihak eksekutif yang merupakan eks pegawai KAP big four. Hal inilah yang menyebabkan keberadaan pihak eksekutif yang pernah bekerja di KAP big four (yaitu KAP big four yang kini tengah mengaudit perusahaan), justru dapat mengurangi praktik manajemen laba yang agresif. Pihak eksekutif ter-sebut tentunya akan menjaga reputasi dirinya maupun reputasi KAP big four tempat mereka dulu bekerja, sehingga mereka tidak ingin terlibat dalam praktik manajemen laba yang dapat merusak repu-tasi dirinya maupun merusak reputasi KAP. Seba-gai konsekuensinya, keberadaan pihak eksekutif seperti ini justru mengurangi praktik manajemen laba yang terlalu agresif.

Implikasi dari penelitian ini bagi otoritas pen-gawas pasar modal di Indonesia adalah perlunya pengawasan terhadap relasi antara pihak eksekutif perusahaan dengan KAP yang kini tengah men-gaudit perusahaan. Hal ini penting untuk mence-gah dirugikannya investor di pasar modal, karena agresifnya praktik manajemen laba yang dilakukan oleh pihak perusahaan.

Penelitian ini memiliki beberapa keterbatasan. Pertama, sampel penelitian yang diambil hanya dari perusahaan manufaktur yang terdaftar di BEI, sehingga tidak sepenuhnya mewakili populasi se-luruh perusahaan yang terdaftar di BEI.Penelitian berikutnya dapat menambah sampel penelitian, tidak hanya pada perusahaan sektor manufaktur namun juga perusahaan yang bergerakdi sektor lainnya.

Kedua, penelitian ini mengukur relasi pihak eksekutif dengan KAP yang mengaudit dengan cara menelusuri profil eksekutif yang tercantum dalam laporan tahunan perusahaan maupun CV yang ada di database google. Penelitian selanjutnya dapat menelusuri berbagai sumber lainnya untuk mengetahui apakah ada relasi yang terjadi antara pihak eksekutif dengan KAP yang mengaudit, mi-salnya melalui: Linked.in, Instagram, Facebook, Twitter, dan lain sebagainya.

\section{DAFTAR PUSTAKA}

Ball, F., Tyler, J., \& Wells, P. (2015). Is audit quality impacted by auditor relationships? Journal of Contemporary Accounting \& Economics 11, 166-181.

Chi, W., Lisic, Ling Lei., \& Pevzner, M. (2011). In Enhanced Audit Quality Associated with Greater Real Earnings Management. Accounting Horizon, 25 (2), 315-335.

Inaam, Z., Khmoussi, H., and Fatma, Z. (2012). Au-dit Quality and Earnings Management in the Tunisian Context. International Journal of Accounting and Financial Reporting, 2(2), 17-33

Jensen, M. C., \& Meckling, W. H. (1976). Theory of The Firm: Managerial. Journal of Financial, 305-360.

Mursalim. (2005). Income Smoothing dan Motivasi Investor: Studi Empiris Pada Investor di BEJ. Income Smoothing dan Motivasi Investor: Studi Empiris Pada Investor di BEJ.

Murwaningsari, E. (2011). Hubungan derivatif keuangan dan discretionary accrual sebagai alat manajemen laba serta pengaruh terhadap relevansi nilai dari laba dan ekuitas. Disertasi Doktoral, Program Pascasarjana Ilmu Akuntansi, Fakultas Ekonomi Universitas Indonesia.

Nachrowi, N. D., \& Usman, H. (2006). Pendekatan Populer dan Praktis EKONOMETRIKA Untuk Analisis Ekonomi dan Keuangan. Jakarta: Lembaga Penerbit Fakultas Ekonomi Univesitas Indonesia .

Nadia, F. N. (2015). PENGARUH TENUR KAP, REPUTASI KAP DAN ROTASI KAP TERHADAP KUALITAS AUDIT. Jurnal Akuntansi Bisnis.

Nuralimah, A. (2017, October 8). SKANDAL BRITISH TELECOM DAN PRICE WATERHOUSE COOPERS. Retrieved from https://atikahnuralimah.wordpress.com/2017/10/08/skandal-british-telecom-danprice-waterhouse-coopers/.

Oktavia. (2017). PENGGUNAAN DERIVATIF KEUANGAN DALAM AKTIVITAS PENGHINDARAN PAJAK DAN MANAJEMEN LABA, SERTA DAMPAKNYA TERHADAP PERSISTENSI LABA DAN KEKELIRUAN PENILAIAN PASAR: ANALISIS LINTAS NEGARA DI ASEAN.Disertasi Doktoral, Program Pascasarjana Ilmu Akuntansi, Fakultas Ekonomi Universitas Indonesia.

Peraturan Menteri Keuangan. (2008). (PMK) No. 17/PMK.01/2008 Tentang Jasa Akuntan Publik. (PMK) No. 17/PMK.01/2008 Tentang Jasa Akuntan Publik. Indonesia.

Peraturan Pemerintah. (2015). Peraturan Pemerintah (PP) No. 20 tahun 2015. Peraturan Pemerintah (PP) No. 20 tahun 2015. Indonesia.

Priantara, D. (2017, Juni Kamis). Ketika Skandal Fraud Akuntansi Menerpa British Telecom dan PwC.https://www.wartaekonomi.co.id/read145257/ketika-skandal-fraud-akuntansi-menerpabritish-telecom-dan-pwc.html. 
Riswandi, P., Kamaludin, \& Midiastuty, P. P. (2012). PENGARUH REPUTASI AUDITOR DAN GOOD CORPORATE GOVERNANCE TERHADAP EARNING MANAGEMENT. Jurnal Fairness Vol 2 no 1, 85-107.

Scott, W. (2015). Financial Accounting Theory. Pearson Education, seventh edition.

Siregar, Sylvia Veronica \& Siddharta Utama. (2008). Type of earnings management and the effect of ownership structure, firm size, and corpo-rate-governance practices: Evidence from In-donesia. The International Journal of Accounting, 43, 1-27.

Wahlen, J. M., \& Heally, P. M. (1999). A Review of the Earnings Management Literature and Its Implications for Standard Setting. Accounting Horizons, 365-385.

Watts, R. L., \& Zimmerman, J. L. (1986). Positive Accounting Theory. Englewood Cliff, NJ: Prentice Hall.

Wisanggeni, Antonius Anandri, \& Imam Ghozali. (2017). Pengaruh Auditor Relationships terhadap Kualitas Audit pada Perusahaan Manufaktur di Indonesia (Studi Empiris pada Perusahaan Manufaktur yang Terdaf-tar pada Bursa Efek Indonesia Tahun 2011). Diponegoro Journal of Accounting, 6, 1-14. 